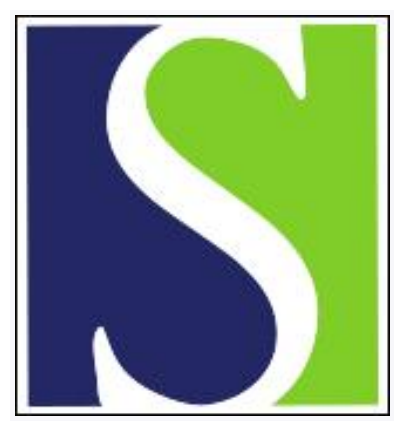

Scand J Work Environ Health 1981;7(4):277-281

https://doi.org/10.5271/sjweh.2551

Issue date: Dec 1981

Chromosome aberrations in cultured human Iymphocytes exposed to trivalent and pentavalent arsenic.

by Nordenson I, Sweins A, Beckman L

Key terms: chromosome aberration; cultured human lymphocyte; exposure; pentavalent arsenic; sister chromatid exchange; smelter worker; trivalent arsenic; urinary arsenic

This article in PubMed: www.ncbi.nlm.nih.gov/pubmed/6897125

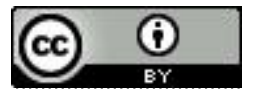




\title{
Chromosome aberrations in cultured human lymphocytes exposed to trivalent and pentavalent arsenic
}

\author{
by Ingrid Nordenson, DrMSc, Agneta Sweins, BSc, Lars Beckman, PhD ${ }^{1}$
}

\begin{abstract}
NORDENSON I, SWEINS A, BECKMAN L. Chromosome aberrations in cultured human lymphocytes exposed to trivalent and pentavalent arsenic. Scand $j$ work environ health 7 (1981) 277-281. Cultured human lymphocytes were exposed to trivalent ( $\mathrm{NaAsO}_{2}$ ) and pentavalent $\left(\mathrm{Na}_{2} \mathrm{HAsO}_{4}\right)$ arsenic in concentrations comparable to the arsenic levels found in the urine of copper smelter workers. Significantly increased frequencies of chromosome aberrations (gaps, chromatid breaks, chromatid exchanges and chromosome breaks) were found after exposure to trivalent but not pentavalent arsenic. This effect was not found when nonstimulated $\left(\mathrm{G}_{0}\right)$ lymphocytes were exposed to trivalent arsenic and then cultured. The rate of sister chromatid exchanges was also found to be increased after exposure to trivalent arsenic. The results suggest that trivalent arsenic is more genotoxic than pentavalent arsenic and that arsenic exerts its effect mainly during cell division.
\end{abstract}

Key terms: smelter workers, sister chromatid exchanges, urinary arsenic.

Arsenic has been reported to be carcinogenic, teratogenic, and mutagenic $(1,5)$. Occupational and environmental exposure to arsenic has attracted increasing interest in recent years (4). The prospect of an increased usage of coal as an energy source, $\mathrm{eg}$, in coal-fired power plants, gives further emphasis to the importance of studying the genotoxic effects of arsenic.

Trivalent arsenic is more toxic than pentavalent arsenic and the major part of ingested or inhaled inorganic arsenic is biotransformed and excreted in the urine as dimethylarsinic acid and methylarsonic acid $(3,17)$.

Increased frequencies of chromosome aberrations have been observed in lymphocytes of individuals exposed to arsenic, eg, wine-growers using arsenic-containing pesticides $(13,15)$, patients given arsenic for therapeutic reasons $(9,13)$, and copper smelter workers (7). Burgdorf et al (2) reported an increased rate of sister chro-

1 Department of Medical Genetics, University of Umeå, Umeå, Sweden.

Reprint requests to: Dr I Nordenson, Department of Medical Genetics, University of Umeå, S-901 85 Umeå, Sweden. matid exchanges (SCEs) in lymphocytes from arsenic treated patients, whereas Nordenson et al (9) found no such increase.

In cultured cells arsenic has been reported to cause mitotic arrest and chromosome damage $(10,11,13,14)$. In a recent study Nakamuro \& Sayato (6) showed that the chromosome-breaking effect in cultured lymphocytes and fibroblasts was significantly higher with trivalent than with pentavalent arsenic. Zanzoni \& Jung (18) found an increased rate of SCEs in human lymphocytes treated in vitro with sodium arsenate.

In this paper we report the results of studies on chromosome aberrations and SCEs in cultured human lymphocytes exposed to trivalent and pentavalent arsenic.

\section{Material and methods}

The experiments were performed on lymphocytes from three different healthy individuals. Lymphocyte culturing, chromosome preparation, and the scoring of chromosome aberrations were done according to previously described methods (8). 
Sodium arsenite $\left(\mathrm{NaAsO}_{2}\right)$ or sodium arsenate $\left(\mathrm{Na}_{2} \mathrm{HAsO}_{4} \times 7 \mathrm{H}_{2} \mathrm{O}\right)$ (Merck) was added to the cultures $24 \mathrm{~h}$ after the start. The arsenic compounds were dissolved in $0.9 \%$ sodium chloride, and four different doses of the compounds were tested (tables $1 \& 2$ ). The cells were exposed for $48 \mathrm{~h}$ before the harvesting. Cultures without the addition of arsenic served as controls.

In order to study the effects of arsenic on cells in the $G_{0}$ phase, the cells were exposed to sodium arsenite for $24 \mathrm{~h}$, washed twice in culture medium, and then grown in fresh medium supplemented with phytohemagglutinin for another $48 \mathrm{~h}$.

The method used for the studies of SCEs was essentially according to Perry \& Wolff (12). The final concentration of bromodeoxouridine was $100 \mu \mathrm{M}$. Sodium arsenite was added $24 \mathrm{~h}$ after the start, and the cultures were harvested $48 \mathrm{~h}$ later. In the scoring of the SCEs, the exchanges in the centromere regions were included in the total frequencies.

\section{Results}

The mitotic activity was found to be decreased in lymphocyte cultures exposed to arsenic, especially $\mathrm{NaAsO}_{2}$. As a result of this cytotoxic effect it was sometimes difficult to find the preferred number of 100 intact cells per experiment.

Table 1 shows the numbers of cells and chromosome aberrations in duplicate experiments with $\mathrm{NaAsO}_{2}$ and $\mathrm{Na}_{2} \mathrm{HAsO}_{4}$ and in controls. There was no heterogeneity between cells from different individuals. The results of the duplicate experiments were essentially the same. Significant differences (on the $5 \%$ level) were found concerning gaps. The frequency of gaps was higher in experiment 1 at the dose

Table 1. Chromosome aberrations in cultured lymphocytes exposed to trivalent and pentavalent arsenic of different doses and in control cultures. The experiment was done in duplicate (experiment 1 and 2).

\begin{tabular}{|c|c|c|c|c|c|}
\hline \multirow[b]{2}{*}{ Dose } & \multirow[b]{2}{*}{$\begin{array}{l}\text { Number of } \\
\text { cells }\end{array}$} & \multicolumn{4}{|c|}{ Aberrations } \\
\hline & & Gaps & $\begin{array}{c}\text { Chromatid } \\
\text { breaks }\end{array}$ & $\begin{array}{c}\text { Chromosome } \\
\text { breaks }\end{array}$ & All \\
\hline \multicolumn{6}{|l|}{ Sodium arsenite } \\
\hline \multicolumn{6}{|l|}{$77 \cdot 10^{-8} \mathrm{M}$} \\
\hline Experiment 1 & 100 & 18 & 3 & 4 & 25 \\
\hline Experiment 2 & 100 & 6 & 0 & 5 & 11 \\
\hline \multicolumn{6}{|l|}{$150 \cdot 10^{-8} \mathrm{M}$} \\
\hline Experiment 1 & 100 & 43 & 13 & 5 & 61 \\
\hline Experiment 2 & 90 & 28 & 8 & 1 & 37 \\
\hline \multicolumn{6}{|l|}{$230 \cdot 10^{-8} \mathrm{M}$} \\
\hline Experiment 2 & 83 & 91 & 22 & 5 & 118 \\
\hline \multicolumn{6}{|l|}{$310 \cdot 10^{-8} \mathrm{M}$} \\
\hline Experiment 1 & 50 & 63 & 19 & 1 & 83 \\
\hline Experiment 2 & 27 & 50 & 9 & 0 & 59 \\
\hline \multicolumn{6}{|l|}{ Sodium arsenate } \\
\hline \multicolumn{6}{|l|}{$77 \cdot 10^{-8} \mathrm{M}$} \\
\hline Experiment 1 & 100 & 1 & 0 & 0 & 1 \\
\hline Experiment 2 & 100 & 6 & 0 & 0 & 6 \\
\hline $150 \cdot 10^{-8} \mathrm{M}$ & & & & & \\
\hline Experiment 1 & 82 & 2 & 0 & 0 & 2 \\
\hline Experiment 2 & 150 & 3 & 4 & 1 & 8 \\
\hline \multicolumn{6}{|l|}{$230 \cdot 10^{-8} \mathrm{M}$} \\
\hline Experiment 1 & 100 & 2 & 1 & 0 & 3 \\
\hline Experiment 2 & 100 & 0 & 0 & 1 & 1 \\
\hline \multicolumn{6}{|l|}{$310 \cdot 10^{-8} \mathrm{M}$} \\
\hline Experiment 1 & 100 & 0 & 0 & 0 & 0 \\
\hline Experiment 2 & 100 & 2 & 1 & 0 & 3 \\
\hline \multicolumn{6}{|l|}{ Control } \\
\hline - & 500 & 9 & 2 & 3 & 14 \\
\hline
\end{tabular}


$77 \cdot 10^{-8} \mathrm{M}$, but higher in experiment 2 at the doses $230 \cdot 10^{-8} \mathrm{M}$ and $310 \cdot 10^{-8} \mathrm{M}$. Those differences were apparently nonsystematic and rather small compared to the differences between doses, and therefore the results of experiments 1 and 2 were combined.

Table 2 shows aberrations per cell after exposure to $\mathrm{NaAsO}_{2}$ and $\mathrm{Na}_{2} \mathrm{HAsO}_{4}$. Increased frequencies of aberrations were found only in cultures exposed to trivalent arsenic $\left(\mathrm{NaAsO}_{2}\right)$. Gaps and chromatid breaks showed a significant and dose-dependent increase. There was also a significant increase in chromosome breaks, but this increase was apparently not doserelated. On the contrary there was a tendency towards a negative correlation between arsenic dose and chromosome breaks.

Chromatid exchanges are a very rare type of aberration. Yet there were 19 such aberrations in 642 cells exposed to trivalent arsenic as compared to none in 832 cells exposed to pentavalent arsenic and 500 control cells.
No increased frequency of aberrations was found when nonstimulated (Go) lymphocytes were exposed to $390 \cdot 10^{-8} \mathrm{M}$ $\mathrm{NaAsO}_{4}$. In 390 cells exposed in $\mathrm{G}_{0}$ only seven gaps, two chromatid breaks, and one chromosome type aberration were found.

Exposure of lymphocytes to $390 \cdot 10^{-8} \mathrm{M}$ $\mathrm{NaAsO}_{4}$ for $24 \mathrm{~h}$ caused an increase in the $\mathrm{SCE}$ rate (table 3 ). The mean per cell increased by $50 \%$, and the difference between the distributions of SCEs in arsenictreated cells and controls was highly significant $\left(\chi^{2}=70.2,3 \mathrm{df}, \mathrm{p}<0.001\right)$.

\section{Discussion}

In this study we found a distinct difference between trivalent and pentavalent arsenic with respect to the clastogenic effect in vitro. Nakamuro \& Sayato (6) also found that trivalent arsenic was more clastogenic. Petres et al $(13,14,15)$, who studied only pentavalent arsenic $\left(\mathrm{Na}_{2} \mathrm{HAsO}_{4}\right)$ in relatively high doses, found a clastogenic effect for this compound. With the

Table 2. Chromosome aberrations per cell in cultured lymphocytes exposed to trivalent and pentavalent arsenic. Significance of difference from preceding dose step or control.

\begin{tabular}{|c|c|c|c|c|}
\hline \multirow{2}{*}{ Dose } & \multicolumn{4}{|c|}{ Aberrations per cell } \\
\hline & Gaps & Chromatid breaks & Chromosome breaks & All \\
\hline \multicolumn{5}{|c|}{ Sodium arsenite } \\
\hline $\begin{array}{r}77 \cdot 10^{-8} \mathrm{M} \\
150 \cdot 10^{-8} \mathrm{M} \\
230 \cdot 10^{-8} \mathrm{M} \\
310 \cdot 10^{-8} \mathrm{M}\end{array}$ & $\begin{array}{l}0.120^{* * *} \\
0.374 * * * \\
0.943 * * * \\
1.468 * * *\end{array}$ & $\begin{array}{l}0.015 \\
0.111 * * * \\
0.211 * \\
0.364 *\end{array}$ & $\begin{array}{l}0.045 \\
0.032 \\
0.034 \\
0.013\end{array}$ & $\begin{array}{l}0.180 \\
0.516 \\
1.189 \\
1.844\end{array}$ \\
\hline \multicolumn{5}{|c|}{ Sodium arsenate } \\
\hline $\begin{array}{r}77 \cdot 10^{-8} \mathrm{M} \\
150 \cdot 10^{-8} \mathrm{M} \\
230 \cdot 10^{-8} \mathrm{M} \\
310 \cdot 10^{-8} \mathrm{M}\end{array}$ & $\begin{array}{l}0.035 \\
0.022 \\
0.010 \\
0.010\end{array}$ & $\begin{array}{l}0.000 \\
0.017 \\
0.005 \\
0.005\end{array}$ & $\begin{array}{l}0.000 \\
0.004 \\
0.005 \\
0.000\end{array}$ & $\begin{array}{l}0.035 \\
0.043 \\
0.020 \\
0.015\end{array}$ \\
\hline \multicolumn{5}{|l|}{ Control } \\
\hline - & 0.018 & 0.004 & 0.006 & 0.028 \\
\hline
\end{tabular}

$* p<0.05, * * * p<0.001$, detemined by the chi-square test.

Table 3. Sister chromatid exchanges (SCEs) in lymphocytes exposed to trivalent arsenic and in controls.

\begin{tabular}{|c|c|c|c|c|c|c|c|}
\hline \multirow{2}{*}{ Dose } & \multicolumn{4}{|c|}{ Distribution of SCES } & \multirow{2}{*}{ Mean } & \multirow{2}{*}{$S D$} & \multirow{2}{*}{$\begin{array}{l}\text { Number of } \\
\text { cells }\end{array}$} \\
\hline & $0-5$ & $6-10$ & $11-15$ & $>15$ & & & \\
\hline $\begin{array}{l}\text { Sodium arsenite }\left(390 \cdot 10^{-8} \mathrm{M}\right) \\
\text { Sontrol }\end{array}$ & $\begin{array}{l}0 \\
7\end{array}$ & $\begin{array}{l}24 \\
91\end{array}$ & $\begin{array}{l}37 \\
10\end{array}$ & $\begin{array}{r}13 \\
0\end{array}$ & $\begin{array}{r}12.47 \\
8.16\end{array}$ & $\begin{array}{l}3.63 \\
1.86\end{array}$ & $\begin{array}{r}74 \\
108\end{array}$ \\
\hline
\end{tabular}


doses of pentavalent arsenic used in our experiments no significant increase of chromosome aberrations was found. It seems likely, however, that there is a clastogenic effect also of pentavalent arsenic, but in considerably higher doses than with trivalent arsenic. With respect to the types of aberrations found in the experiments with arsenical compounds, there are both differences and similarities between our investigation and that by $\mathrm{Na}-$ kamuro \& Sayato. A similarity is that in both investigations a relatively high frequency of chromatid exchanges was found.

Differences between the two investigations occurred with respect to the distributions of gaps, chromatid breaks, and chromosome breaks. Thus Nakamuro \& Sayato recorded no chromosome breaks, and they found fewer gaps in comparison with our study. These differences may be due to variations between laboratories with respect to the routines for classifying and recording aberrations.

In our study there was an almost linear increase of gaps and chromatid breaks with (trivalent) arsenic dose. This observation is in agreement with the findings of Nakamuro \& Sayato. Chromosome breaks showed no such dose-dependence. There was, on the contrary, a tendency towards a decrease of chromosome breaks at higher doses. An explanation for this lack of dose-dependence may be that the cytotoxic effect slows down the rate of cell proliferation and also kills a large fraction of cells with chromosome damage. Since chromosome type aberrations can be observed only in the second cell division in cells exposed to a mutagen during $\mathbf{S}$ or $\mathrm{G}_{2}$ phases, higher doses of arsenic may cause a marked decrease of cells in second cell division and thereby decrease the possibilities to observe chromosome breaks.

The mode of action of arsenic is not known. In Escherichia coli arsenic has been shown to inhibit deoxyribonucleic acid (DNA) repair (16), and in human lymphocytes arsenic has been found to inhibit the incorporation of nucleotides into DNA and ribonucleic acid and to block the cells in the $S$ and $G_{2}$ phases (13). We found no increase in chromosome damage after exposure of lymphocytes to arsenic in the $\mathrm{G}_{0}$ phase. Thus arsenic seems to exert its effect mainly during cell division. Arsenic may not be directly clastogenic per se, but could nevertheless have a genotoxic effect, eg, by interfering with the DNA repair or by interacting with different enzyme systems. Trivalent arsenicals are sulfhydryl reagents, which inhibit a large number of thiol-dependent enzyme systems, while pentavalent arsenicals have a lower affinity for hydroxy and thiol groups and inhibit fewer enzyme systems (5).

Our results concerning the effect of arsenic on the rate of SCEs should be looked upon as preliminary until confirmed in further experimental studies. The information on the relationship between in vivo exposure to arsenic and SCEs is scanty, and the results from the only two studies known to us $(2,9)$ were contradictory. The study by Zanzoni \& Jung (18) on the effect of in vitro exposure to arsenic is difficult to evaluate. The authors claim to have studied inorganic trivalent arsenic, but the chemical formula contradicts this statement.

Our experiments indicate that trivalent arsenic in the doses used produces gaps, breaks and SCEs. The arsenic concentrations in the culture medium were of the same order of magnitude as the arsenic concentrations in the urine of copper smelter workers. In 33 smelter workers examined by us the mean level of urinary arsenic was $306 \mu \mathrm{g} / 1\left(408 \cdot 10^{-8} \mathrm{M}\right)$ with a range of $110-1,080 \mu \mathrm{g} / 1 \quad\left(147-1,440^{\circ}\right.$ $\left.10^{-8} \mathrm{M}\right)$. The doses used in our experiments varied between 60 and $390 \mu \mathrm{g} / \mathrm{l}$ $\left(77 \cdot 10^{-8}\right.$ and $390 \cdot 10^{-8} \mathrm{M}$, respectively). The concentrations of arsenic in urine and in cell cultures are, however, not comparable with respect to their toxicity since the major part of ingested or inhaled inorganic arsenic appears to be biotransformed and excreted as methylated species $(3,17)$. In preliminary experiments with dimethylarsinic acid $\left(\mathrm{C}_{2} \mathrm{H}_{7} \mathrm{AsO}_{2}\right)$ in the same dose range as in the experiments with sodium arsenite, we have found no clastogenic effect.

Thus our results indicate that the genotoxic effect of occupational arsenic exposure may be ascribed mainly to the fraction of trivalent arsenic that is not detoxified by methylation in the body.

A better understanding of arsenic genotoxicity would require further studies of arsenic metabolism, including individual 
variability and also the interaction of arsenic with other toxic substances. Smelter workers, eg, may be exposed to arsenic, as well as sulfur dioxide and lead.

\section{Acknowledgment}

This investigation was supported by The Swedish Work Environment Fund.

\section{References}

1. Bencko V. Carcinogenic, teratogenic and mutagenic effects of arsenic. Environ health perspect 19 (1977) 179-182.

2. Burgdorf W, Kurvink K, Cervenka J. Elevated sister chromatid exchange in lymphocytes of subjects treated with arsenic. Hum genet 36 (1977) 69-72.

3. Crecelius EA. Changes in the chemical speciation of arsenic following ingestion by man. Environ health perspect 19 (1977) $147-150$.

4. Fowler BA, ed. International conference on environmental arsenic, Ft Lauderdale, Florida Oct. 1976. Environ health perspect 19 (1977) $239-242$.

5. Léonard A, Lauwerys, RR. Carcinogenicity, teratogenicity and mutagenicity of arsenic. Mutat res 75 (1980) $49-62$.

6. Nakamuro K, Sayato $\mathrm{Y}$. Comparative studies of chromosomal aberration induced by trivalent and pentavalent arsenic. Mutat res 88 (1981) $73-80$.

7. Nordenson I, Beckman G, Beckman L, Nordström S. Occupational and environmental risks in and around a smelter in northern Sweden: II. Chromosomal aberrations in workers exposed to arsenic. Hereditas 88 (1978) $41-50$.

Received for publication: 7 May 1981
8. Nordenson I, Beckman G, Beckman L, Rosenhall L, Stjernberg $N$. Is exposure to sulphur dioxide clastogenic? Chromosomal aberrations among workers at a sulphite pulp factory. Hereditas 93 (1980) 161-164.

9. Nordenson I, Salmonsson S, Brun E, Beckman G. Chromosome aberrations in psoriatic patients treated with arsenic. Hum genet 48 (1979) 1-6.

10. Oppenheim $J$, Fishbein W. Induction of chromosome breaks in cultured normal human leucocytes by potassium arsenite, hydroxyurea and related compounds. Cancer res 25 (1965) 980-985.

11. Paton G, Allison AC. Chromosomal damage in human cell cultures induced by metal salts. Mutat res 16 (1972) 332-336.

12. Perry P, Wolff S. New Giemsa method for the differential staining of sister chromatids. Nature 251 (1974) 156-158.

13. Petres J, Baron D, Hagedorn M. Effects of arsenic cell metabolism and cell proliferation: Cytogenetic and biochemical studies. Environ health perspect 19 (1977) 223-227.

14. Petres J, Hundeiker M. "Chromosomenpulverisation" nach Arseneinwirkung und Zellkulturen in vitro. Arch Klin Exp Derm 231 (1968) 366-370.

15. Petres J, Schmid-Ullrich K, Wolff U. Chromosomenaberrationen an menschlichen lymphozyten bei chronischen arsenschäden. Dtsch Med Wochenschr 2 (1970) 79-80.

16. Rossman T, Meyn S, Troll W. Effects of sodium arsenite on the survival of UV-irradiated Escherichia Coli: Inhibition of a rec-A-dependent function. Mutat res 30 (1975) 157-162.

17. Smith TJ, Crecelius EA, Reading JC. Airborn arsenic exposure and excretion of methylated arsenic compounds. Environ health perspect 19 (1977) 89-93.

18. Zanzoni F, Jung EG. Arsenic elevates the sister chromatide exchange (SCE) rate in human lymphocytes in vitro. Arch dermatol res 267 (1980) 91-95. 